$$
\text { リチウムスピネル } \mathrm{Zn}_{1-x} \mathrm{Li}_{\mathrm{x}} \mathrm{Fe}_{2-\mathrm{x}} \mathrm{Ti}_{\mathrm{x}} \mathrm{O}_{4}(\mathrm{x}=0.0 \sim 1.0) \text { のイオン分布 }
$$

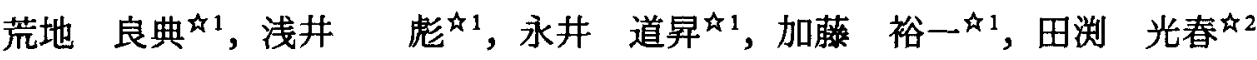 \\ 41 関西大学工学部, 干 564-8680 吹田市山手町 3-3-35.

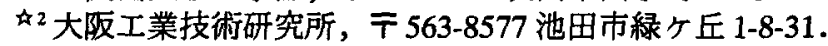

\title{
Ion Distribution of Spinel Type $\mathrm{Zn}_{1-x} \mathrm{Li}_{x} \mathrm{Fe}_{2-x} \mathrm{Ti}_{x} \mathrm{O}_{4}$
}

\author{
Yoshinori Arachi ${ }^{\star 1}$, Takeshi Asai ${ }^{\star 1}$, Michinori Nagai ${ }^{\star 1}$, Yuichi Katoh ${ }^{\star 1}$ and Mitsuharu Tabuchi ${ }^{\not 2}$ \\ ${ }^{4}$ Chemical Branch, Faculty of Engineering, Kansai University, 3-3-35 Yamate-cho, Suita 564-8680. \\ * 2 Osaka National Research Institute, 1-8-31 Midorigaoka, Ikeda 563-8577.
}

Received December 4, 2000

\section{SYNOPSIS}

The substitution of $\mathrm{Li}^{+}$for $\mathrm{Zn}^{2+}$ and $\mathrm{Ti}^{4+}$ for $\mathrm{Fe}^{3+}$ in $\mathrm{ZnFe}_{2} \mathrm{O}_{4}$ with the spinel stype structure was adopted to obtain the fundamental understanding of the $\mathrm{Li}$ ion conduction in solids. The cation distribution of the compound was investigated at the starting research. The $\mathrm{XRD}$ patterns indicated the formation of the solid solution, $\mathrm{Zn}_{1-\mathrm{x}} \mathrm{Li}_{\mathrm{x}} \mathrm{Fe}_{2-\mathrm{x}} \mathrm{Ti}_{\mathbf{x}} \mathrm{O}_{4}$ and the lattice parameter decreased linearly with the increase of $x$ in accordance with the ionic radius for each cation. Above $\mathrm{x}=0.6$ a slight curvature appeared in the composition dependence of the lattice parameter. The Rietveld analysis determined the cation distribution for the present system. It can be written as $\mathrm{Zn}_{1-\mathrm{x}} \mathrm{Fe}_{\mathrm{x}}^{\left[{ }^{[8]}\right]}\left[\mathrm{Li}_{\mathrm{x} / 2} \mathrm{Fe}_{1-\mathrm{x}} \mathrm{Ti}_{\mathrm{x} / 2}\right]^{[16 \mathrm{~d}]}{ }_{2} \mathrm{O}_{4}$ (for $\mathrm{x}<0.5$ ). It showed that $\mathrm{Li}^{+}$occupies the octahedral (16d)site, whereas $\mathrm{Fe}^{3+}$ occurs on the tetrahedral (8a) site. $\mathrm{Li}^{+}$ had a preference for $16 \mathrm{~d}$ sites up to $\mathrm{x}=0.5$. On the other hand, $\mathrm{Li}^{+}$starts out going to the tetrahedral site above a concentration of 0.5 . The cation distribution can be written as $\mathrm{Zn}_{1-x} \mathrm{Fe}_{0.5} \mathrm{Li}_{\mathrm{x}-0.5}{ }^{[8 \mathrm{a}]}\left[\mathrm{Li}_{0.25} \mathrm{Fe}_{(1.5-\mathrm{x}) 2} \mathrm{Ti}_{\mathrm{x} / 2}\right]^{[16 \mathrm{da}]} \mathrm{O}_{4}$ (for $\mathrm{x}>0.5$ ). The observed change in the composition dependence of the lattice parameter is caused by the change of the cation distribution in the spinel structure. In addition, the iron distribution for the present system was confirmed by the Mössbauer spectroscopy. The electrochemical lithium insertion was also discussed.

KEY WORDS

Spinel type structure, Cation distribution, Rietveld analysis, Lithium secondary batterry

\section{1 緒 霉}

リチウム含有スビネル型化合物は骨格構造を有し，Liイオ ンがその構造中を容易に拡散することから, リチウム二次電 池用電極材料として広く研究されている"1. 四面体位置にある Li(8a)は, 空のサイトである八面体位置(16c)を介して拡散し， 従って,この構造中には Li の拡散経路が三次元的に存在する2). 例えば，同様の構造を示す $\mathrm{Li}_{4} \mathrm{Ti}_{5} \mathrm{O}_{12}$ は理想的なインサーショ ン電極材料として知られている. リチウムはスピネル構造中

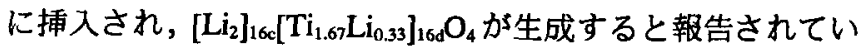

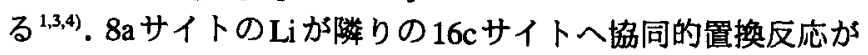
起こると説明されている.我々はこのスピネル型構造に注目 し, 構造とリチウムイオンの拡散との関係を基礎的な観点か ら明らかにすることを目的としている.本研究では,その出発 段階として, 同様の構造を示す $\mathrm{ZnFe}_{2} \mathrm{O}_{4}$ を取り上げ, $\mathrm{Zn}$ を $\mathrm{Li}$ ， 電荷補償のために $\mathrm{Fe}$ を $\mathrm{Ti}$ で固換させた系 $\left(\mathrm{Zn}_{1-\mathrm{x}} \mathrm{Li}_{\mathrm{x}} \mathrm{Fe}_{2-\mathrm{x}} \mathrm{Ti}_{\mathrm{x}} \mathrm{O}_{4}\right.$ $(\mathrm{x}=0.0$ 1.0)) について合成を試み，リートベルト解析，およ びメスバウアー分光法によりイオン分布を中心に検討した. また, 電気化学的な手法により $\mathrm{Li}$ の挿入・脱離について検討 を行った。

\section{2 実験}

試料の調製は通常の固相法より行った. 出発物質 $\mathrm{ZnO}$, $\mathrm{Li}_{2} \mathrm{CO}_{3}, \mathrm{TiO}_{2}$ (anatase), $\mathrm{Fe}_{2} \mathrm{O}_{3}$ の所定量を秤量後, ボールミルにて エタノール溶媒中湿式混合した. 乾燥後, ペレット状に加圧成 型し，焼成した。焼成条件は仮焼 $873 \mathrm{~K} 6$ 時間，本焼 $1323 \mathrm{~K} 6$ 時 間である.得られた試料は粉末X線回折湘定によって結晶相の 同定, およびプログラムRietan $97 \beta$ を用いたリートベルト解析

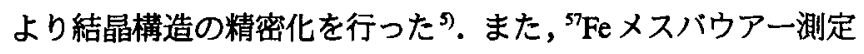
により $\mathrm{Fe}$ のイオン分布の検討を行った. さらに, ヒーカ一型三 極式セル (参照極, 対極 : $\mathrm{Li}$, 作用極 : 試料 $75 \mathrm{mg}$, アセチレン 
ブラック $20 \mathrm{mg}$, テフロン $5 \mathrm{mg}$, 電解液 $1 \mathrm{MLiClO}_{4} / \mathrm{EC}: \mathrm{DME}=1: 1$ 体積比)を用いサイクリックボルタモメトリー,および定電流 充放電試験 (二極式セル, cut off 電位: $1.0-3.5 \mathrm{~V}$, 電流密度: $\left.0.17 \mathrm{~mA} / \mathrm{cm}^{2}\right)$ により室温にてLiの㨂入・脱離反応を検討した.

\section{3 結果と考察}

\section{1 結晶構造}

得られた試料の XRD パターンを Fig.1に示す. 全てのピー クをスピネル型立方晶として指数付けすることができ，単一 相形成を確認した. すべてのピークが高角度側にシフトして いることから格子定数の隇少が予想される。 また，ピーク強 度が相对的に変化していることから構造因子の変化が起こっ ている可能性がある. Fig.2に立方晶の格子定数， $a$ 軸の組成 依存性を示す. 格子定数は $\mathrm{x}$ の增加に伴い，ほぼ直線的に減 少したことから $\mathrm{Zn}$ や $\mathrm{Fe}$ より小さいイオン半径をもつ Li と Ti が置換し，固溶体が形成したと考えられる.しかし， $\mathrm{x}=0.6$ 付 近で直線は屈曲し隇少率が変化したことから, 何らかの分布 の変化が予想される.リートベルト解析には通常のスビネル 型構造に用いられる空間群 $\mathrm{Fd} \overline{3} \mathrm{~m}, \mathrm{Zn}$ は 8a, Feは 16d, Oは

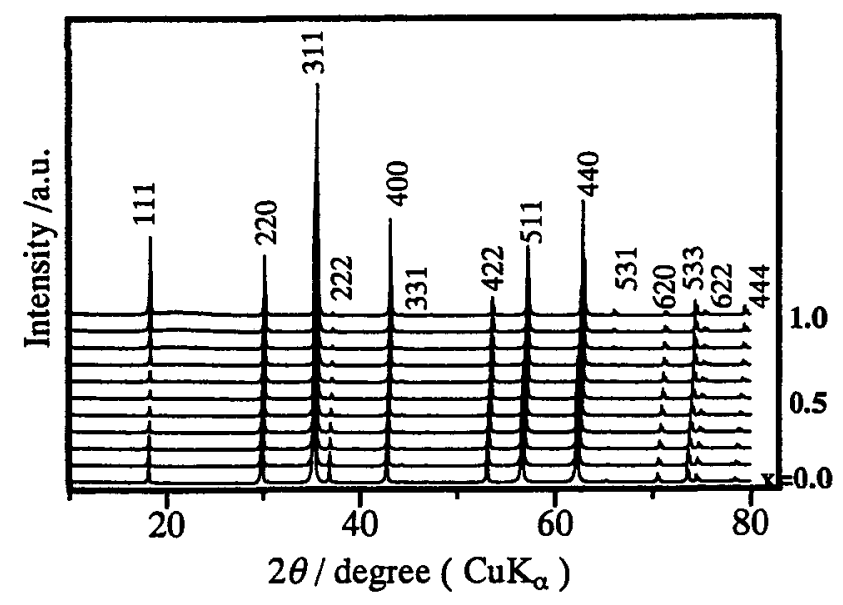

Fig.1 XRD patterns of $\mathrm{Zn}_{1-x} \mathrm{Li}_{x} \mathrm{Fe}_{2-x} \mathrm{Ti}_{\mathrm{x}} \mathrm{O}_{4}$.

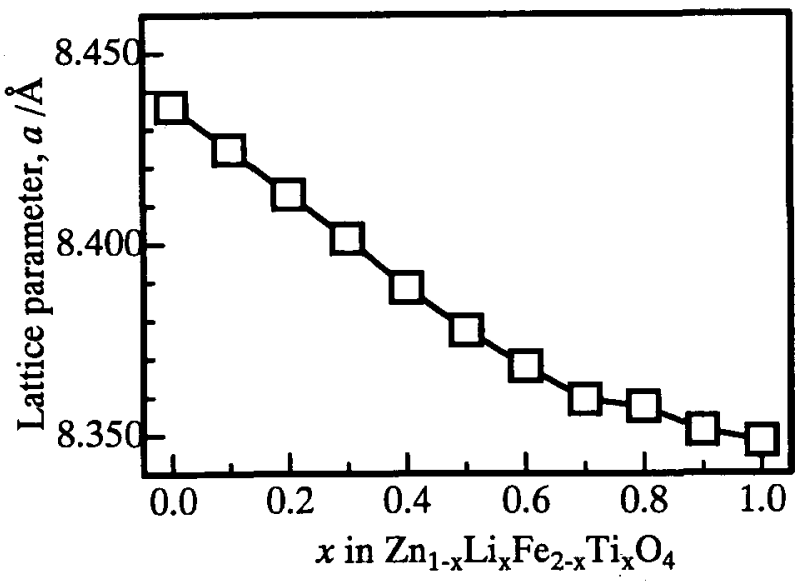

Fig.2 Composition dependence of the cubic lattice parameter for $\mathrm{Zn}_{1-x} \mathrm{Li}_{\mathbf{x}} \mathrm{Fe}_{2-\mathrm{x}} \mathrm{Ti}_{\mathbf{x}} \mathrm{O}_{4}$.
$32 \mathrm{e}$ サイトに存在するという構造モデルを用い, $\mathrm{x}=0.0$ につい て良好な解析結果が得られた。一方, Li, Ti含有系については， $\mathrm{Zn}$ は8 $\mathrm{a}$ ，Ti は 16d のみに存在すると仮定し，それらの占有率 は固定し他のカチオンについて占有率をパラメーターとして 解析を進めた。 $x=0.0$ については $R_{\mathrm{E}}=11.53$ に対し $R_{w p}=17.23$, $R_{p}=11.90, R_{1}=2.26$ であり,また $x=0.5$ については $R_{E}=10.95$ に対し, $\mathbf{R}_{\mathrm{wp}}=15.84, \mathrm{R}_{\mathrm{p}}=11.27, \mathbf{R}_{\mathrm{I}}=2.52$ を示し, 他の組成につ いてもほぼ同様の結果であった。これらの解析結果を検証す るために, 各々のサイト中のカチオンと酸素の平均結合距離 を求めた (Fig.3). 計算値とリートベルト解析より得られた值 が, 全組成範囲に渡ってわずかの誤差にとどまり，よく似た 変化を示した. 従って,この解析結果は良好に進んだと考え られる. x=1.0については, S. Scharner et. alによる報告と一 致した ${ }^{6,7}$. また, 8a サイト中のカチオンと酸素との結合距離 の減少か顕著なことから, 格子定数の減少は四面体の変化に よることが分かる. 次に，解析結果から得られた $8 \mathrm{a}, 16 \mathrm{~d}$ 両サ イトにおける各々のカチオン占有率の組成依存性をFig.4に示 す.すべての組成について Znは $8 \mathrm{a}, \mathrm{Ti}$ は 16dサイトに存在す ると仮定し解析を進めた. Li のドープに伴い，Liは16dサイ

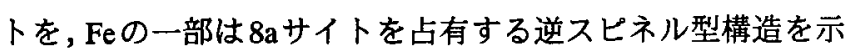
した。この組成領域では，Liは八面体指向性が強いことが分 かる. しかし，さらに Liをドーブすると，16dサイトの占有 率はほぼ 0.25 で餲和し，四面体位置を占有するように変化し た。以上のことから，
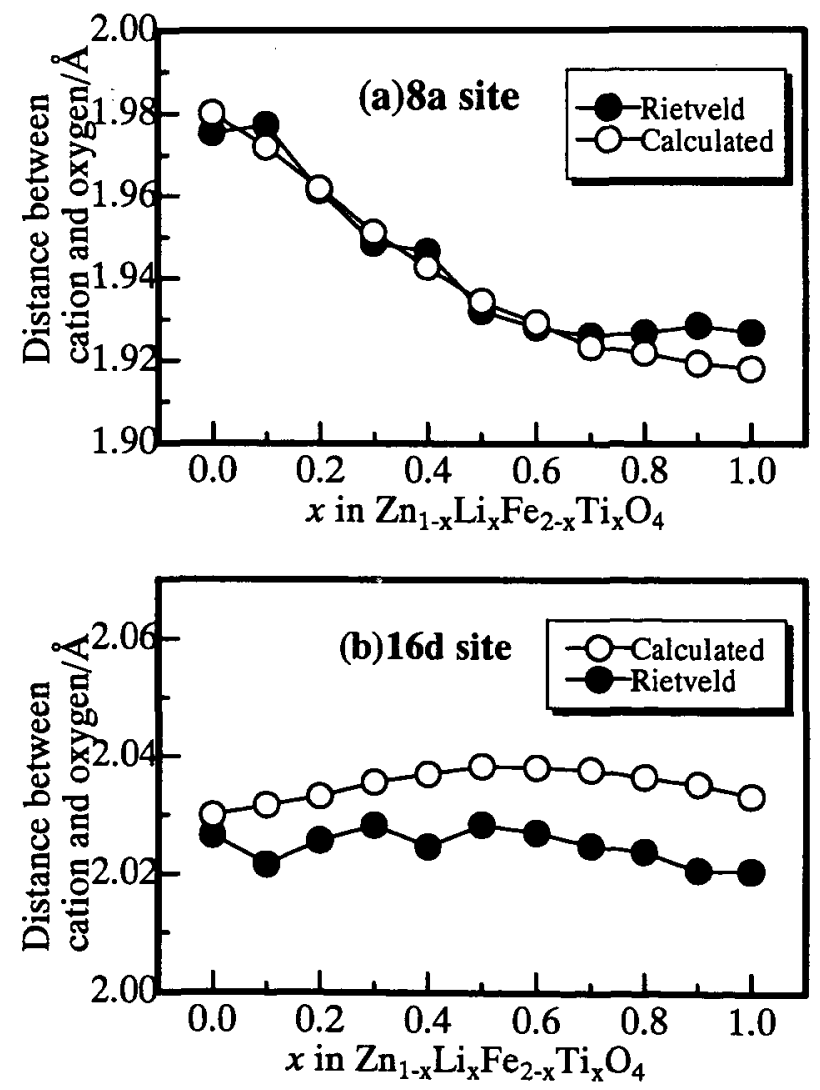

Fig.3 Composition dependence of the distance between cation and oxygen at (a) $8 \mathrm{a}$ and (b) $16 \mathrm{~d}$ site for $\mathrm{Zn}_{1-x} \mathrm{Li}_{x} \mathrm{Fe}_{2-\mathrm{x}} \mathrm{Ti}_{x} \mathrm{O}_{4}$. 

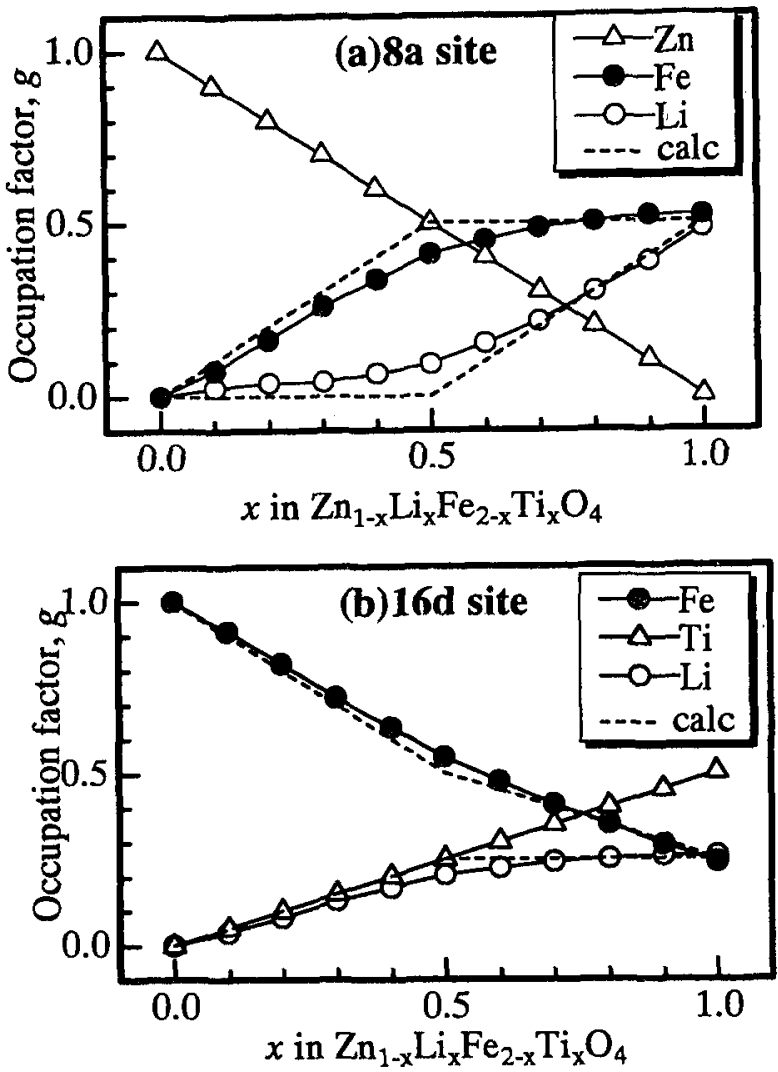

Fig.4 Composition dependence of the occupation factor $g$ in (a) the 8a site and (b) the $16 \mathrm{~d}$ site for spinel structure, $\mathrm{Zn}_{1-x} \mathrm{Li}_{\mathrm{x}}$ $\mathrm{Fe}_{2-\mathrm{x}} \mathrm{Ti}_{\mathbf{x}} \mathrm{O}_{4}$.

$\mathrm{x}<0.5$ では $\mathrm{Zn}_{1-x} \mathrm{Fe}_{\mathrm{x}}^{\left[{ }^{[8]}\right]}\left[\mathrm{Li}_{\mathrm{x} / 2} \mathrm{Fe}_{1-\mathrm{x}} \mathrm{Ti}_{\mathrm{x} / 2}\right]^{[16 d]} \mathrm{O}_{4}$,

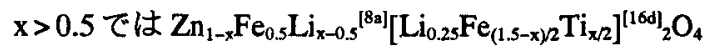

のように分布することが明らかになった.従って, $\mathrm{x}=0.6$ を境 に見られた格子定数の不連続な変化は，この様なイオンの配 列変化と対応していると考えられる. 次に, 室温におけるメ スバウアー分光测定結果を Fig.5に示す. $x=0.0$ について，ス ペクトルは doublet1成分でフィットでき, 構造中の Feのサイ

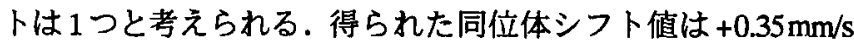
でほほ酸素 6 配位の高スピン $\mathrm{Fe}^{3+}$ のみと考えられる。また doubletのみであることから室温で常磁性体であることが分か

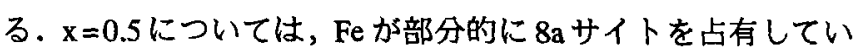
るため磁気転移が起こり始めている.同位体シフト值が+0.36 $\mathrm{mm} / \mathrm{s} の$ doublet と同位体シフト値が $+0.3-0.4 \mathrm{~mm} / \mathrm{s}$ で内部磁場 が20-36Tの 4 本の sextetの重ね合わせで解析を行った.いず れも Feは高スピン 3 価の状熊で存在している. 通常, 高スピ ン $\mathrm{Fe}^{3+}$ の sextetは内部磁場が 45-50Tであるが，転移温度に近 いためこのような低い値になっていると考えられる.一方， $\mathrm{x}=1.0\left(\mathrm{LiFeTiO}_{4}\right)$ についても，x=0.5 とほぼ同様に解析でき， 同位体シフト值が $+0.28 \mathrm{~mm} / \mathrm{s} の$ doublet と同位体シフト値が $+0.3-0.4 \mathrm{~mm} / \mathrm{s}$ で内部磁場が $14-28 \mathrm{~T} の 4$ 本の sextet の重ね合 わせで解析した。これより，Feは高スピン 3 価の状態で存在 していることが分かった。
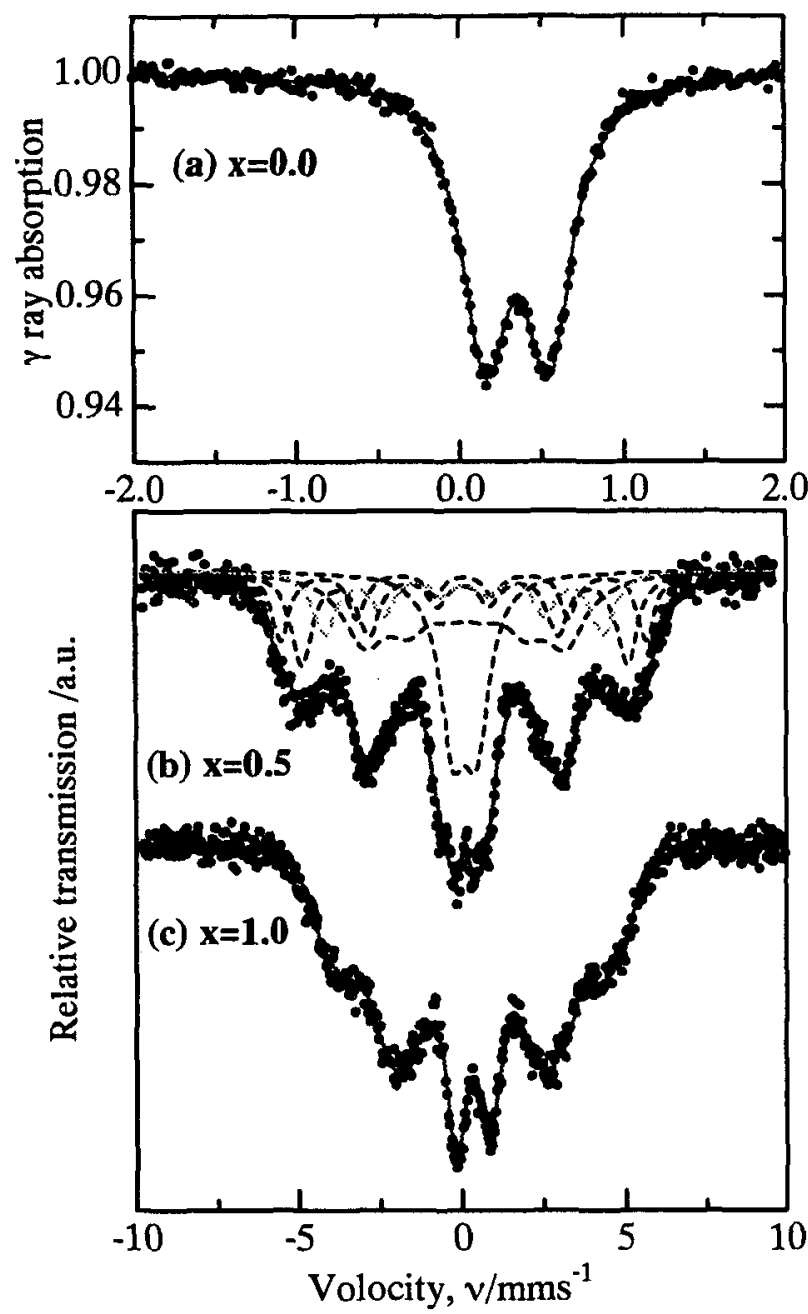

Fig.5 Mössbauer spectroscopy of $\mathrm{Zn}_{1-x} \mathrm{Li}_{x} \mathrm{Fe}_{2-x} \mathrm{Ti}_{x} \mathrm{O}_{4}$ at R.T.: (a) $\mathrm{x}=0.0$, (b) $x=0.5$ and (c) $x=1.0$.

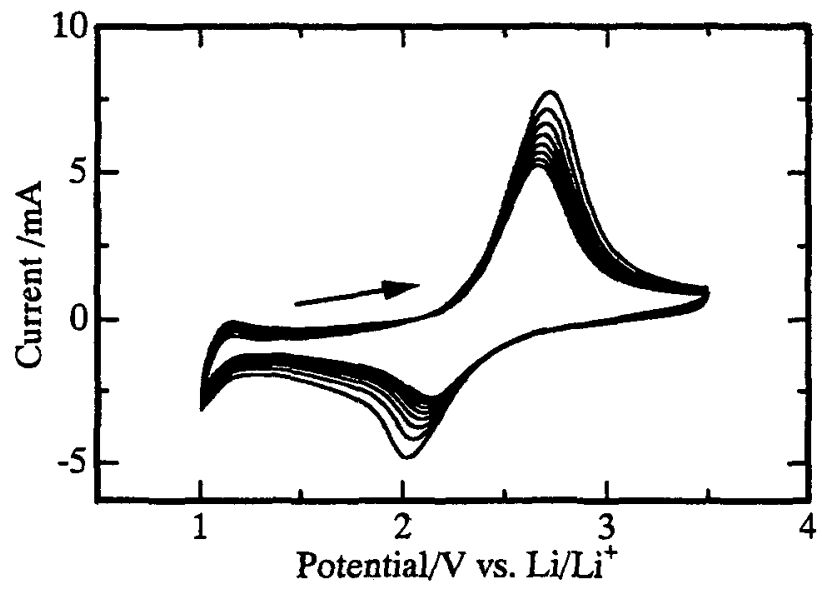

Fig.6 Cyclic voltammograms of $\mathrm{LiFeTiO}_{4}$ (for $\mathrm{x}=1.0$ in $\mathrm{Zn}_{1-\mathrm{x}} \mathrm{Li}_{\mathrm{x}}$ $\mathrm{Fe}_{2-x} \mathrm{Ti}_{x} \mathrm{O}_{4}$ ) at $1.0 \mathrm{mV} / \mathrm{sec}$ taken in $1 \mathrm{M} \mathrm{LiClO}_{4} / \mathrm{EC}$ (Ethylen Carbonate): DME (1,2-dimethoxyethane $)=1: 1$ by volume. Electrode consists of $85 \mathrm{mg} \mathrm{LiFeTiO}{ }_{4}, 10 \mathrm{mg}$ acetylen black and $5 \mathrm{mg}$ teflon binder.

\section{2 電気化学的りチウム挿入・脱離}

$\mathrm{x}=1.0$ について電気化学的な $\mathrm{Li}$ の挿入・脱離をサイクリッ 


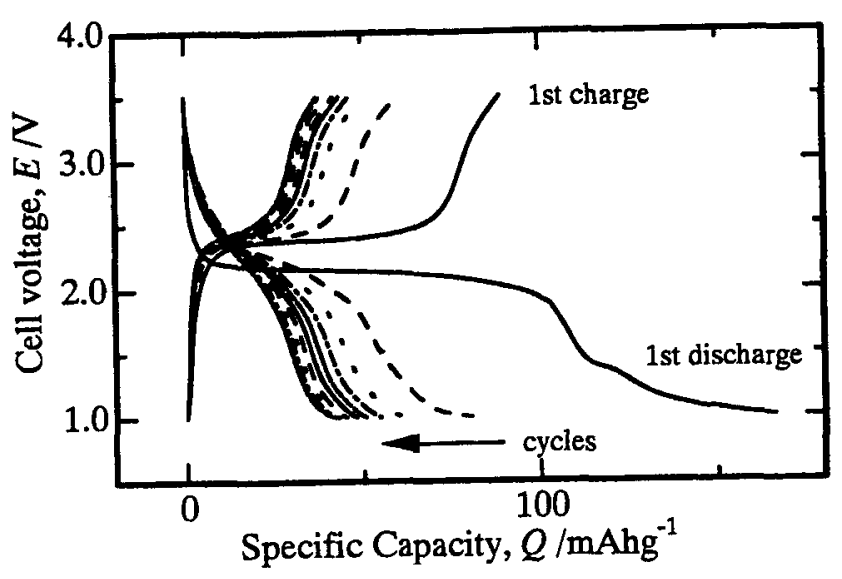

Fig.7 Charge/discharge curves for $\mathrm{Li}_{2} / \mathrm{LiFeTiO}_{4}$ cell through 10 cycles with cut-off voltage of $1.0-3.5 \mathrm{~V}$ and at a current density of $0.17 \mathrm{~mA} / \mathrm{cm}^{2}$.

クボルタモメトリーにより試みた(Fig.6). 初期電位 3.1Vから

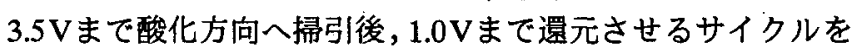
重ねた.1サイクル目において 2.1 と $1.0 \mathrm{~V}$ 付近に還元電流, ま た2.7Vで酸化電流ピークが観察されたことから,構造中の Li の脱離反応はなく, 外部から取り込まれた Liが可逆的に出し 入れしていると考えられる. 定電流充放電試験の結果を Fig.7 に示す.一回目の放電曲線に $2.1 \mathrm{~V}$ 付近に平坦部が現れ，1.3V 付近では不可逆な反応が観測され約 $170 \mathrm{mAhg}^{-1}$ の容量を示し， Li が挿入された. 理論容量 $\left(153 \mathrm{mAhg}^{-1}\right)$ と比較して, 電解液 の分解も含まれている可能性がある. 一方, 充電曲線では $2.3 \mathrm{~V}$ 付近に平坦部が現れ $90 \mathrm{mAhg}^{-1}$ の容量を示し, $\mathrm{Li}$ が脱離 されたが, 大きな不可逆容量を示した.この物質では初期サ イクルにて二段階で Liを取り込み，一段階で Liを放出する反 応を示唆し, サイクリックボルタモメトリーの結果と符合し た. Li は空の八面体位置である 16c サイトに取り込まれたと 考えられる.また，電流值はわずかに減少するがサイクルを 重ねてもピークは観察されたことから，Liイオンの可逆的な 挿入・脱離反応が可能であることが分かる.一方, 他の組成 については $\mathrm{x}$ の隇少，つまり $\mathrm{Zn}, \mathrm{Fe}$ の含有量が増加するに従 い, 両電流ピークは小さくなり電気化学的に不活性な性質を 示した。しかし，先に述べたイオン分布を踏まえると， $\mathrm{Fe}^{3+}$ か
四面体位置に存在するにも関わらずLiの挿入が可能であった $\mathrm{x}=1.0$ に対して，Znが四面体位置に存在する他の組成で Li挿 入が不可能であった原因については明らかになっていない. Liの拡散と構造との関係を明らかにするためにもI i イオン輸 率测定を現在進めている。

\section{4 結 論}

スピネル型構造を示す $\mathrm{Zn}_{1-\mathrm{x}} \mathrm{Li}_{\mathrm{x}} \mathrm{Fe}_{2-\mathrm{x}} \mathrm{Ti}_{\mathrm{x}} \mathrm{O}_{4}(\mathrm{x}=0$ ～1.0) を合成 し，X線回折湘定によるリートベルト解析，およびメスバウ アー分光法により次のようなイオン分布を示すことが明らか になった。

$$
\begin{aligned}
& x<0.5, \mathrm{Zn}_{1-\mathrm{x}} \mathrm{Fe}_{\mathrm{x}}{ }^{[8 \mathrm{a})}\left[\mathrm{Li}_{\mathrm{x} / 2} \mathrm{Fe}_{1-\mathrm{x}} \mathrm{Ti}_{\mathrm{x} / 2]^{116 \mathrm{~d}]}{ }_{2} \mathrm{O}_{4},}\right. \\
& \mathrm{x}>0.5, \mathrm{Zn}_{1-\mathrm{x}} \mathrm{Fe}_{0.5} \mathrm{Li}_{\mathrm{x}-0.5}{ }^{[8 \mathrm{~g}]}\left[\mathrm{Li}_{0.25} \mathrm{Fe}_{(1.5-\mathrm{x}) / 2} \mathrm{Ti}_{\mathrm{x} / 2}\right]^{[16 \mathrm{~d}]} \mathrm{O}_{4}
\end{aligned}
$$

また, $\mathrm{x}=1.0\left(\mathrm{LiFeTiO}_{4}\right)$ のみ室温にて電気化学的 $\mathrm{Li}$ 挿入・脱 離が可能であり, $\mathrm{Fe}^{2,3+}$ の酸化還元を伴った反応と考えられる.

\section{文献}

1) M.M.Thackeray: "Spinel Electrodes for Lithium Batteries", J. Am. Ceram. Soc., 82(1999)3347-3354.

2) 菅野了次: "リチウム二次電池材料の結晶構造と材料特性", 日本結晶学会誌, 40(1998)262-271.

3) E.Ferg, R.J.Gummow, A.de Koch and M.M.Thackeray: "Spinel Anodes for Lithium-Ion Batteries", J. Electrochem. Soc., 141 (1994)L147-L150, S.Scharner, W.Weppner and P.ScmidBeurmann, J. Solid State Chem., 134(1997)170-181.

4) T.Ohzuku, A.Ueda and N.Yamamoto: "Zero-Strain Material of $\mathrm{Li}\left[\mathrm{Li}_{1 / \beta} \mathrm{Ti}_{5 / \beta}\right] \mathrm{O}_{4}$ for Rechargeable Lithium Cells", J. Electrochem. Soc., 142(1995)1431-1435.

5) F.Izumi: The Rietveld Method (R.A.Young Ed.), Chapter 13, Oxford University Press, Oxford, (1993)236-253.

6) S.Scharner, W.Weppner and P.Scmid-Beurmann: "Cation Distribution in Ordered Spinels of $\mathrm{Li}_{2} \mathrm{O}-\mathrm{TiO}_{2}-\mathrm{Fe}_{2} \mathrm{O}_{3}$ System", J. Solid State Chem., 134(1997)170-181.

7) S.Scharner, W.Weppner and P.Scmid-Beurmann: "Evidence of Two-Phase Formation upon Lithium Insertion into the $\mathrm{Li}_{1.33} \mathrm{Ti}_{1.67} \mathrm{O}_{4}$ Spinel", J. Electrochem. Soc., 146(1999)857-861. 